Egyptian Journal of Rabbit Science, 27 (2): 309- 323(2017)

\title{
IMPACT OF ADDING CITRIC, LACTIC ACIDS AND PROPYLENE GLYCOL. 1. GROWING RABBITS PERFORMANCE
}

\author{
H. M. Kelawy*; A. A. Sedki**; M. M. Nassrallah**; Noha, M. A. **; \\ Samia M. Mobarez and Manal S., Mohamed** \\ *Faculty of Technology and Development, Zagazig University, Zagazig, Egypt. \\ **Animal Production Research Institute, Agriculture Research Center, \\ Dokki, Giza, Egypt.
}

The purpose of the present study was to determine if individual citric, lactic acids, propylene glycol or mixture of them supplementing to drinking water would have a beneficial effect on performance of growing rabbits or not. Seventy five weaned New Zealand White (NZW) rabbits, 5 weeks of age with an average ( $651 \pm 22 \mathrm{~g})$ were divided into five groups (15 rabbits in each). Rabbits of group (1) received plain water, rabbits of groups 2,3,4 received water supplemented with $0.5 \mathrm{ml} /$ Litter citric, lactic or Propylene glycol. Fifth group received a combination of Citric + Llactic + Propylene glycol with $0.25 \mathrm{ml} / \mathrm{Litter}$ of each. Rabbits were fed ad libitum on a commercial diet containing $17 \%$ $C P$ and $2700 \mathrm{Kcal}$ DE. The study was continued during fattening period, from 6-12 weeks of age.

The results showed that, citric, lactic acids or propylene glycol separately or combined decreased significantly total anaerobic bacterial, E.coli count, cecum $\mathrm{pH}$ and ammonia concentration in cecum contents. Treatments increased significantly lactobacilli counts and total volatile fatty acids in the cecum contents. Mixture of organic acids and propylene glycol increased significantly the hematocrit values, white blood cells counts, plasma globulin and lymphocyte percentage while decrease blood $\mathrm{pH}$. Values of total protein, albumin and each of plasma AST and ALT increased but within the normal range. Significant improvement were observed in body weight gain, feed conversions and viability percentage during fattening period

Conclusively, it can be concluded that supplementation of citric, lactic acids or propylene showed a great role in enhancing the immune system, improved growth performance, blood metabolites that due to improving cecum media as a results of increase total VFAs production and decrease each of total anaerobic bacterial and cecum $\mathrm{pH}$ which finally minimize pathogenic bacteria and digestive disorders. 
Key words : Citric \& lactic acids,- propylene glycol, rabbits, growth.

Rabbit stomach normally has a very low (acidic) $\mathrm{pH}$ (1 to 2 ) that effectively kills pathogenic microorganisms. Weanling rabbits have a stomach $\mathrm{pH}$ of 5 to 6.5 and weanling diarrhea develops because this stomach $\mathrm{pH}$ is not acidic enough to destroy opportunistic pathogens (Fekete,1989). Weanlings, however, must go through this period of a higher stomach $\mathrm{pH}$ to allow the growth of symbiotic microbial populations in the gut. Young rabbits, before eight weeks of age, have a sterile hindgut because of the antibacterial action of rabbit milk. They also have a high stomach $\mathrm{pH}$ (alkaline or 5+) that does not neutralize ingested bacteria so bacteria are allowed to colonize the cecum. Young rabbit should have sufficient intestinal and cecal bacteria for digestion about two weeks after weaning (McWilliams, 2001).Organic acids act as growth promoting factor, by improving the immune system. They reduce pathogenic microorganisms simultaneously increase the beneficial bacteria, which reflect on improving the digestive system and lead to more gain (Noha et al,2006).

Propylene glycol is a precursor for glucose synthesis and reduced ketone concentrations in blood also used to promote growth or production. Trace elements occur naturally in most ingredients. The amount and bioavailability varies considerably according to their existence as parts of complex molecules which are not fully broken down during digestion; and the degree to which minerals are absorbed from the small intestine and hence available at the cell level (Smits and Henman, 2000). Through digestion the minerals ions are released and can re-combine with other digesta components in the intestine to form insoluble compounds, thereby reducing their absorption across the small intestine. Throughout complexion the element with an organic molecule of amino acids or peptides, the bioplex mineral, or protein are prevented from breaking down into reactive ions during digestion.

Propylene glycol is a widely used compound with diverse applications and in many commercial animals (Luzi et al,2000).It is a polyhydric alcohol $(\mathrm{C} 3 \mathrm{H} 8 \mathrm{O} 2)$ which is a colorless, odorless liquid with mildly acrid and sweetish taste. It is freely soluble in water and ethanol. It has been extensively employed in the pharmaceutical industry as a solvent for drugs, as stabilizer for vitamins and in pastes for medicinal purposes (Seidenfeld and Hanzlik, 1932). Propylene glycol and organic acids are main components in several commercial products that used as acidifiers such as Acitrol and Cynertox. 
Therefore, the objective of the present work was to study the effect of a special supplementation of organic acids and propylene on growth performance and immune parameters of growing rabbits.

\section{MATERIALS AND METHODS}

This study was carried out at a private rabbitry in east Dakahlia Governorate. The fieldwork was continued from April to June 2014.A total of healthy seventy five New Zealand White rabbits about 5 weeks of age was assigned to five experimental groups (15 per group) and averaged initial live body weight $(651 \pm 22 \mathrm{~g})$. All rabbits were randomly placed in individual wire cages. Rabbits were fed a commercial diet containing $17 \%$ $\mathrm{CP}$ and $2700 \mathrm{Kcal}$ DE (Table 1). Water was supplemented with different acidifiers. The $1^{\text {st }}$ group received plain water and severed as control, while the other four groups received water with different supplementations according to commercial products (Table 2). All rabbits were kept under the same managerial hygienic and environmental conditions throughout the experimental period.

Feed and water were provided ad libitum. Body weight, feed consumption, body weight gain and feed conversion were recorded. At the end of the experiment, blood samples $(3 \mathrm{ml})$ were collected from the marginal ear vein in heparinized test tubes to determine some physiological parameters. Hematocrit values $(\mathrm{Ht} \%)$, hemoglobin concentration $(\mathrm{Hb}, \mathrm{g} / \mathrm{dl})$ and white blood cells counts (WBCs, $10^{3} / \mathrm{ml}$ ) were determined in fresh blood samples. White blood cells differential were performed according to Hawkey and Dennett (1989). Blood plasma was separated by centrifugation and kept at $-20^{\circ} \mathrm{C}$ for assessments of triiodothyronine $\left(\mathrm{T}_{3}\right)$ using commercial kits and radioimmunoassay technique, levels of hormone were determined according to procedure outlined by manufacturer of commercial kits. Total protein was determined according to (Merck, 1974), albumin to (Dumas et al., 1971). Plasma minerals were also determined. Cecum content samples were taken from three animals in each group after slaughter at the end of the experiment. Cecum fluid content was obtained, after slaughter, to count total anaerobic bacteria and E.Coli in their selective media as described by Collins et. al. (1995). In addition, cecum $\mathrm{pH}$ was measured by using $\mathrm{pH}$ meter in filtrate cecum content. Cecal ammonia nitrogen concentration was determined by Conway and Kjelleberg (1989). Total volatile fatty acids were determined by Eadie et al. (1967). 
Table1: The ingredients and chemical composition of the basal diet.

\begin{tabular}{ll}
\hline Ingredients & \% \\
\hline Wheat bran & 24.0 \\
Egyptian clover hay & 36.0 \\
Barley grains & 20.0 \\
Soybean meal (44\%) & 15.0 \\
Molasses & 2.85 \\
Limestone & 1.4 \\
NaCl & 0.25 \\
Premix* & 0.25 \\
DL- Methionine & 0.25 \\
\hline Total & $\mathbf{1 0 0}$ \\
\hline Calculated analysis** & \\
Digestible energy (DE),kcal/kg & 2530 \\
Crude protein (CP), \% & 17.0 \\
Crude fiber (CF), \% & 12.4 \\
EE & 2.3 \\
Methionine & 0.90 \\
L-Lysine, \% & 0.84 \\
\hline
\end{tabular}

*Premix each kilogram contains:

Vit. A, 6000 IU; Vit. D, 900 IU; Vit. E, 40 mg; Vit. K3, 2 mg; Vit. B1, 2 mg; Vit. B2, 4 mg; Vit. B6, $2 \mathrm{mg}$; Vit. B12, $10 \mu \mathrm{cg}$; Nicotinic acid, $50 \mathrm{mg}$; Biotin, $50 \mu \mathrm{cg}$; Folic acid, $10 \mathrm{mg}$; Choline chloride, $250 \mathrm{mg}$; Zinc, $50 \mathrm{mg}$; Manganese, $85 \mathrm{mg}$; Iorn, $50 \mathrm{mg}$; Copper, $5 \mathrm{mg}$; Iodine, $0.2 \mathrm{mg}$; Selenium, $0.1 \mathrm{mg}$; Cobalt, $0.1 \mathrm{mg}$.

Table 2: Different supplementations as treated groups.

\begin{tabular}{|l|l|c|}
\hline Groups & Supplementation & $\begin{array}{c}\text { Supplementation } \\
\text { rate (ml/Litre) }\end{array}$ \\
\hline G1 & Control & Plain water \\
\hline G2 & Citric acid & 0.5 \\
\hline G3 & Lactic acid & 0.5 \\
\hline G4 & Propylene glycol & 0.5 \\
\hline G5 & Citric 0.25 + Lactic $0.25+$ Propylene 0.25 & 0.75 \\
\hline
\end{tabular}

Data were subjected to the analysis of variance using General Linear Model (GLM) of SAS , (2004). One-way analysis of variance was carried out according to Sendecor and Cochran (1982) using the following model: $\mathrm{Y} \mathrm{ij}=\mu+\mathrm{Ti}+\mathrm{Eij}$.

Where Yij $=$ individual observation, $\mu=$ Overall mean, $\mathrm{Ti}=$ The effect of treatments, $\mathrm{Eij}=$ The experimental random error. 
The significant differences between the means were tested using Duncan's Multiple Range test (Duncan, 1955).

\section{RESULTS AND DISCUSSION}

\section{Microbial content of rabbits cecum:}

Supplementation of organic acids and propylene on Microbial content of rabbits cecum are shown in Table 3

Anaerobic bacterial count of cecum contents for all treated groups were lower significantly $(\mathrm{P} \leq 0.05)$ than that of the control that ranged between 5.1 to $6.6 \times 10^{6}$. Organic acids and propylene glycol tended to decrease total anaerobic bacterial count in the cecum contents, which lead to decrease the $\mathrm{pH}$ of the cecum content and then, it weakens the growth of most pathogenic bacteria. These results are in agreement with Miller (1987) and Noha, et.al., (2013). Total anaerobic bacterial count decreased significantly $(\mathrm{P} \leq 0.05)$ in all treatment groups as compared to that of the control group, which may be due to reduce of the cecum $\mathrm{pH}$ (Fuller, 1986) who concluded that, organic acids, inhibiting the growth of pathogenic bacteria.

E.coli count ranged between 550 to $740.6 \times 10^{2}$ in cecum content. All treated groups were lower significantly ( $\mathrm{P} \leq 0.05)$ than that of the control (Table 3). Similar results were obtained by El-Allawy (2001) and Noha et al., (2013). Organic acids and propylene glycol individually or in a combination, may play a role as antimicrobial substrates. Pollman (1986) showed that organic acids change enteric flora and reduce E-Coli content. It also, decrease intestinal $\mathrm{pH}$, produce antibiotic substances and reduce toxic amines and ammonia levels in the gastrointestinal tract and blood.

The $\mathrm{pH}$ values of the cecum contents of all treated groups were lower significantly $(\mathrm{P} \leq 0.05)$ than the control and ranged between 5.8 to 6.5 . Similar results were obtained by El-Allawy (2001) and Noha, et.al. (2013). Organic acids and propylene glycol tended to decrease the $\mathrm{pH}$ of the cecum contents, that weakness the growth of most pathogenic bacteria. These results are in agreement with Abdel-Azeem, et.al., (2000) and Noha, et.al. (2013). Lactobacilli counts in the cecum increased significantly $(\mathrm{P} \leq 0.05)$ in treated groups compared to control. Supplementation of mixture of citric, lactic acids and propylene glycol tended to increase lactobacilli count due to their action by enhance bactaria such as Lactobacillus spp. and Bifidobacterium spp. (Asano et al., 1994). Propylene glycol can be phosphorylated, converted to acetol phosphate, lactaldehyde phosphate, lactyl phosphate, and lactic acid. 
Table 3. Least square means of total anaerobic bacteria (total count $\times 10^{6}$ ), Escherichia coli (E.coli x $10^{2}$ ), Cecum pH, lactobacilli, ammonia $(\mathrm{mg} / 100 \mathrm{ml})$ and total volatile fatty acids $(\mathrm{ml} \mathrm{eq} / 100 \mathrm{ml})$ of growing NZW rabbits as affected by different treatments

\begin{tabular}{|l|c|c|c|c|c|c|}
\hline $\begin{array}{l}\text { Treatment } \\
\text { groups }\end{array}$ & $\begin{array}{c}\text { Total } \\
\text { anaerobic } \\
\text { bacteria }\end{array}$ & E.coli & $\begin{array}{c}\text { Cecum } \\
\text { pH }\end{array}$ & $\begin{array}{c}\text { Lacto } \\
\text { bacilli }\end{array}$ & $\begin{array}{c}\text { Ammonia } \\
\text { mg } \\
/ 100 m l\end{array}$ & $\begin{array}{c}\text { TVF'S ml } \\
\text { eq } \\
/ 100 m l\end{array}$ \\
\hline Control & $6.6^{\mathrm{a}}$ & $740.6^{\mathrm{a}}$ & $6.5^{\mathrm{a}}$ & $3.55^{\mathrm{c}}$ & $8.4^{\mathrm{a}}$ & $3.27^{\mathrm{c}}$ \\
Citric acid (Ci) & $6.0^{\mathrm{bc}}$ & $694.8^{\mathrm{b}}$ & $6.1^{\mathrm{b}}$ & $4.78^{\mathrm{b}}$ & $8.2^{\mathrm{b}}$ & $3.36^{\mathrm{bc}}$ \\
Lactic acid (La) & $5.9^{\mathrm{c}}$ & $622.0^{\mathrm{c}}$ & $5.9^{\mathrm{c}}$ & $4.75^{\mathrm{b}}$ & $7.9^{\mathrm{b}}$ & $3.38^{\mathrm{bc}}$ \\
Propylene glycol (Pg) & $5.8^{\mathrm{c}}$ & $609.4^{\mathrm{c}}$ & $5.9^{\mathrm{c}}$ & $4.82^{\mathrm{b}}$ & $7.8^{\mathrm{b}}$ & $3.37^{\mathrm{bc}}$ \\
Ci +Pg+La & $5.1^{\mathrm{d}}$ & $555.0^{\mathrm{d}}$ & $5.8^{\mathrm{d}}$ & $5.12^{\mathrm{a}}$ & $7.0^{\mathrm{c}}$ & $3.52^{\mathrm{a}}$ \\
\hline SEM & 0.1 & 9.9 & 0.05 & 0.05 & 0.05 & 0.04 \\
\hline
\end{tabular}

a,b,c,...:Means within the same column with different superscripts are significantly different.(P $\leq 0.5)$.

Metabolism of D and L forms of propylene glycol in this pathway is species-specific. The rabbit converts the L-form of phosphorylated propylene glycol to lactic acid, whereas the rat and mouse can convert both forms Miller and Bazzano (1965).

Ammonia concentration in cecum of rabbits was significantly $(\mathrm{P} \leq 0.05)$ decreased in all treated group compared to control group. Moreover, supplementation of citric, lactic acids and propylene glycol tended to increase total volatile fatty acids in the caecum of rabbits individual form or in mixture form. Poeikhampha et al. (2007) and Poeikhampha and Bunchasak (2010) reported that increased the lactic acid bacteria population leading to produce lactic acid and acetic acid. It is believed that increasing acids utilizing bacteria increase total VFAs production (Asano et al., 1994; Tsukahara et al., 2002). The lowest value of cecum $\mathrm{pH}$ in this study lead to improve cecum media as results of increase total VFA ${ }^{\mathrm{s}}$ production.

Propylene glycol, lactic and citric acids, where all these factors well documented as a growth promoters through its effects on increasing the activity of metabolic cycles (citric acid cycle for example), microbial fermentation and reducing the cecal $\mathrm{pH}$, subsequently reduction of the pathogenic load encountered by the animal under farm conditions (Parks et al., 2000) and prohibit the growth of certain intestinal microbes (pathogenic) by increasing the acidity which due to the fermentation of mono-saccharides that (produce volatile fatty acids "VFAs") and the other acid (lactic......etc.). Presences of these acids explain the lower $\mathrm{pH}$ recorded in treated groups. Propylene glycol is oxidised by alcohol 
dehydrogenase to lactaldehyde, then to lactate by aldehyde dehydrogenase. The lactate is further metabolised to pyruvate, carbon dioxide, and water, (ATSDR, 1997). Lactate also contributes to glucose formation through gluconeogenic pathways Christopher et al (1990). Lactate, via phosphoenol pyruvate, can be detoxified into glucose and stored as glycogen, as has been demonstrated by Wittman and Bawin. (1974) for propylene glycol in rats.

Results showed that, total volatile fatty acids ranged between 3.27$3.52 \mathrm{ml} \mathrm{eq} / 100 \mathrm{ml}$.Organic acids and propylene glycol tended to decrease the TVF'S that may be due to that, rabbits naturally affected with diarrhoea showed no notable change in their volatile fatty acid content but a rise of caecal $\mathrm{pH}$ to 7.2. The $\mathrm{pH}$-elevation caused a decrease in the proportion of the non-dissociated volatile fatty acid molecules, and a consequent disappearance of the inhibitor effect.

\section{Blood parameters}

Supplementation of organic acids and propylene on hematocrit value (Ht,\%), hemoglobin concentration $(\mathrm{Hb}, \mathrm{g} / \mathrm{dl})$, blood $\mathrm{PH}$, total white blood cells $(103 / \mathrm{mm} 3)$ and differential counts of white blood cells of growing rabbits are presented in Table 4.

Hematocrit value ranged between 28.5-33.8 \%. These values were within the normal range (29.4-41.5\%) as reported by Ashour (2001) and ElKholy (2003). Supplementation of organic acids mixture (citric, lactic acids and propylene glycol) increased the hematocrit values significantly $(\mathrm{P} \leq 0.05)$ over the control group .These results may be due to a synergetic effect between the organic acids and propylene glycol. The increase in hematocrit values may be a result of the reduced stress on the animal through reducing the pathogenic organisms and good utilization of feed .

Hemoglobin concentration $(\mathrm{Hb}, \mathrm{g} / \mathrm{dl})$ of rabbits ranged between 10.4$11.2 \mathrm{~g} / \mathrm{dl}$. Similar results were obtained by Arrington and Kelly (1976) and Ashour (2001). Differences in hemoglobin concentration between treatments were insignificant. Blood $\mathrm{pH}$ values ranged between 7.26-7.61 and decreased significantly $(\mathrm{P} \leq 0.05)$ in all treatments compared to control but within the normal rang. These results are in agreement with those of Ismail et al., (2002). They reported that the range of blood $\mathrm{pH}$ was 7.3-7.6 in NZW rabbits. Supplementation with organic acids ( lactic, acetic and citric ) individually or in a mixture decreased blood $\mathrm{pH}$ significantly $(\mathrm{P} \leq 0.05)$ over the control. 
Table 4: Least square means of hematocrit value $(\mathrm{Ht}, \%)$, hemoglobin concentration $(\mathrm{Hb}, \mathrm{g} / \mathrm{dl})$, blood $\mathrm{PH}$, total white blood cells $(103 / \mathrm{mm} 3)$ and differential counts of white blood cells of growing NZW rabbits as affected by different treatments.

\begin{tabular}{|c|c|c|c|c|c|c|c|c|c|}
\hline \multirow[b]{2}{*}{$\begin{array}{l}\text { Treatment } \\
\text { groups }\end{array}$} & \multirow[b]{2}{*}{$\begin{array}{l}\circ \\
\vdots \\
\end{array}$} & \multirow[b]{2}{*}{$\begin{array}{l}\bar{\Xi} \\
\text { है } \\
\hat{E}\end{array}$} & \multirow[b]{2}{*}{$\begin{array}{l}\frac{\pi}{2} \\
\frac{2}{0} \\
\frac{0}{0}\end{array}$} & \multirow{2}{*}{ 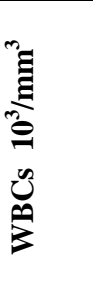 } & \multicolumn{5}{|c|}{ White Blood Cells" } \\
\hline & & & & & $\begin{array}{l}0 \\
\text { E } \\
\text { s. }\end{array}$ & $\begin{array}{l}\stackrel{0}{0} \\
\dot{\bar{z}} \\
\dot{z}\end{array}$ & $\begin{array}{l}\stackrel{0}{0} \\
\dot{\Xi} \\
\dot{0}\end{array}$ & 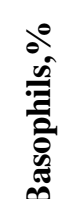 & ڤ̊ \\
\hline Control & $28.5^{\mathrm{c}}$ & 10.5 & $7.61^{\mathrm{a}}$ & $26.4^{\mathrm{b}}$ & $54.6^{\mathrm{b}}$ & $38.9^{\mathrm{abc}}$ & $2.3^{\mathrm{ab}}$ & $2.2 \mathrm{a}$ & $1.7^{\mathrm{ab}}$ \\
\hline Citric acid, $\mathrm{Ci}$ & $30.3^{\mathrm{bc}}$ & 10.5 & $7.30^{b}$ & $26.5^{\mathrm{b}}$ & $54.2^{b}$ & $40.0^{\mathrm{abc}}$ & $2.1^{\mathrm{ab}}$ & $1.8^{\mathrm{ab}}$ & $2.1^{\mathrm{ab}}$ \\
\hline Lactic acid, La & $33.8^{\mathrm{ab}}$ & 11.0 & $7.27^{\mathrm{b}}$ & $26.9^{b}$ & $53^{8 b}$ & $40.7^{\mathrm{ab}}$ & $2.3^{\mathrm{ab}}$ & $1.9^{\mathrm{ab}}$ & $1.8^{\mathrm{ab}}$ \\
\hline Propylene glycol, Pg & $31.2^{\mathrm{bc}}$ & 11.2 & $7.28^{b}$ & $26.8^{b}$ & $54.1^{\mathrm{b}}$ & $40.0^{\mathrm{abc}}$ & $2.7^{\mathrm{a}}$ & $2.2^{\mathrm{a}}$ & $1.3^{\mathrm{b}}$ \\
\hline $\mathrm{Ci}+\mathrm{Pg}+\mathrm{La}$ & $31.1^{\mathrm{bc}}$ & 10.4 & $7.26^{b}$ & $30.3^{\mathrm{a}}$ & $59.4^{\mathrm{a}}$ & $36.0^{\mathrm{bc}}$ & $2.0^{\mathrm{b}}$ & $2.1^{\mathrm{ab}}$ & $2.0^{\mathrm{ab}}$ \\
\hline \begin{tabular}{|l|} 
SEM \\
\end{tabular} & 1.31 & 0.2 & 0.005 & 1.1 & 0.1 & 1.7 & 0.2 & $\mathbf{0 . 1}$ & 0.2 \\
\hline
\end{tabular}

$\mathrm{a}, \mathrm{b}, \mathrm{c}, \ldots$ :..Means within the same column with different superscripts are significantly different. $(\mathrm{P} \leq 0.5)$.

White blood cells count of growing rabbits ranged between $26.4 \times 10^{3} / \mathrm{mm}^{3}$ for control group and $30.3 \times 10^{3} / \mathrm{mm}^{3}$ for mixture of citric, lactic acids and propylene glycol. Mixture supplementation increased white blood cells counts significantly over the control and other treatments. This trend could be through the stimulation of the immune responses (Pollman,1986).Lymphocyte percentage increased significantly in the combination treated group, compared to the control and group received separate organic acids and propylene glycol. Neutrophils, monocytes, basophils and eosinophils percentage showed variable trends in all treatments but within normal range. It was clearly noted that, adding any organic acids, propylene glycol or their combination to the drinking water, of growing rabbits, lead to improving the immune response (increase WBCs, lymphocytes). These results are in agreement with El-Kholy (2003) who found that WBCs increased by using synertox. Also Ismail et al., (2002) reported that WBCs increase by using acitrol.

Supplementation of organic acids and propylene on total protein (TP, $\mathrm{g} / \mathrm{dl}$ ), albumin (Alb, g/dl) aspartate aminotransferase (AST, $\mu / \mathrm{dl})$ and alanine aminotransferase (ALT, $\mu / \mathrm{dl}$ ) of growing rabbits are presented in Table 5.

Plasma total protein ranged between 5.3 to $6.9 \mathrm{~g} / \mathrm{dl}$. Results indicated that adding mixture of citric, lactic acids and propylene glycol to drinking water had the highest value of total protein than other groups that may be due to an increase in the hepatic function. The organic acids may act 
Table 5: Least square means of total protein (TP, g/dl), albumin (Alb, g/dl ) aspartate aminotransferase (AST, $\mu / \mathrm{dl}$ ) and alanine amino transferase (ALT, $\mu / \mathrm{dl}$ of growing NZW rabbits as affected by different treatments.

\begin{tabular}{|c|c|c|c|c|c|c|c|c|}
\hline $\begin{array}{l}\text { Treatment } \\
\text { gruops }\end{array}$ & $\hat{\underline{\theta}}$ & ह & 을 & & $\underset{3}{5}$ & $\frac{\bar{z}}{3}$ & 㦼。 & 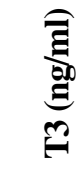 \\
\hline Control & $5.3^{\mathrm{b}}$ & 3.5 & $1.9^{\mathrm{c}}$ & 1.7 & $22.95^{\mathrm{a}}$ & $13.92^{\mathrm{a}}$ & 1.65 & $1.7^{\mathrm{ab}}$ \\
\hline Citric acid, $\mathbf{C i}$ & $5.3^{\mathrm{b}}$ & 3.3 & $2.4^{\mathrm{b}}$ & 1.4 & $32.55^{\mathrm{b}}$ & $21.49^{\mathrm{b}}$ & 1.51 & $2.1^{\mathrm{ab}}$ \\
\hline Lactic acid, La & $6.0^{\mathrm{b}}$ & 3.4 & $2.6^{\mathrm{b}}$ & 1.4 & $32.20^{\mathrm{b}}$ & $19.87^{\mathrm{b}}$ & 1.62 & $1.9^{\mathrm{ab}}$ \\
\hline Propylene glycol, Pg & $6.0^{\mathrm{b}}$ & 3.3 & $2.7^{\mathrm{b}}$ & 1.2 & $31.84^{\mathrm{b}}$ & $20.99^{\mathrm{b}}$ & 1.52 & $1.6^{\mathrm{b}}$ \\
\hline $\mathrm{Ci}+\mathbf{P g}+\mathbf{L a}$ & $6.9^{\mathrm{a}}$ & 3.4 & $3.3^{\mathrm{a}}$ & 1.1 & $32.21^{\mathrm{b}}$ & $19.89^{\mathrm{b}}$ & 1.62 & $2.5^{\mathrm{a}}$ \\
\hline SEM & 0.92 & 0.10 & 0.11 & & 0.24 & 0.29 & & 0.3 \\
\hline
\end{tabular}

a,b,c, :Means within the same column with different superscripts are significantly different.(P $\leq 0.5)$.

through affecting the metabolic rate beside its effect on the gastro-intestinal beneficial microbial. Similar results were obtained by Noha et al., (2013). There were insignificant effects $(\mathrm{P} \leq 0.5)$ of treatments on plasma albumin values. Plasma globulin levels ranged between 1.8 to $3.3 \mathrm{~g} / \mathrm{dl}$ after. Supplementation of citric , lactic acids and propylene glycol individual or mixture increased significantly $(\mathrm{P} \leq 0.05)$ plasma globulin levels over the control. Highest levels of plasma globulin was in the combination group. Plasma Albumin/Globulin ratios ranged between 1.1 to 1.7.

Plasma aspartate aminotransferase (AST, $\mu / \mathrm{dl}$ ) of NZW rabbits ranged between 22.95 to 32.55 . AST value decreased significantly in all treated groups but was within the normal range and no symptoms of toxicity were observed indicating a normal function of the liver. Plasma aspartate aminotransferase increased receiving any combination of the organic acids compared to that of the control group after one and two months from starting the treatments. However, this increase was within the normal range. These results are in agreement with those of Sedki et al., (2002) and Noha, et al., (2013). Plasma alanine aminotransferase (ALT, $\mu / \mathrm{dl}$ ) ranged between 13.9 to 21.5 .ALT decreased significantly $(\mathrm{P}<0.05)$ in all treated groups. 
However, the decrease in ALT levels was within the normal range. These results are in agreement with those of Sedki et al., (2002) and Noha, et al.,(2013).

Succinic acid resulting from decarboxylation of ketoglutaric acid in the citric acid cycle can be converted to the "active" form by linkage with coenzyme A. This active succinate and glycine are together involved in the first step of heme biosynthesis. This fact can explain and present another interpretation for increasing the hemoglobin value and hematocreat \%. In spite of decrease in AST and ALT activities in treated groups ups compared to control group, this decrease within normal range and with no symptoms of toxicosis were observed. This decrease can be attributed to the inclusions of additives to a lot of factors which can affect on liver activity

\section{Growth performance traits}

Supplementation of organic acids and propylene on initial body weight, final body weight, body weight gain, feed conversion and viability percentage of growing rabbits are presented in Table 6 .

At 12 weeks of age, there were higher significant $(\mathrm{P} \leq 0.05)$ in body weight of most treated groups as compared to the control. Similar results were obtained by Noha, et al.(2013), which may be due to positive influences of supplementations on rabbits growth performance, which improved digestibility as substrates in the intermediary metabolism of minerals and vitamins.

Body weight gain of growing NZW rabbits was significantly $(\mathrm{P} \leq 0.05)$ high when compared to the control group. These results reflect the positive increase in the digestibility also is the inhibition of intestinal bacteria competing with the host for available nutrients. A reduction of possibly toxic bacterial metabolites, such as ammonia and amines, leads to improving weight gain of the host animal. This conclusion is in agreement with Kirchgessner and Roth (1988).

Feed conversions of control rabbits, tended to be significantly $(\mathrm{P} \leq 0.05)$ worst value $(4.17 \mathrm{~g})$ than treated groups receiving citric \& lactic acids and propylene glycol individually or as mixture. Improve feed conversions may be due to an increase in the efficiency of nutrition absorption and/or nutrients utilization.

Viability percentage ranged between 90 to $100 \%$. Results indicated that organic acids and propylene glycol supplementation increased viability during the post-weaning period which may be due to decrease the pathogenic microbial and so that improvement of digestibility and increase 
Table 6: Least square means of initial body weight, final body weight, gain, feed conversion and viability percentage of growing NZW rabbits as affected by different treatments, during weaning marketing.

\begin{tabular}{|l|c|c|c|c|c|}
\hline \multicolumn{1}{|c|}{$\begin{array}{c}\text { Treatment } \\
\text { groups }\end{array}$} & $\begin{array}{c}\text { Initial live } \\
\text { weight }(\mathbf{g})\end{array}$ & $\begin{array}{c}\text { Final live } \\
\text { weight } \\
\text { (g) }\end{array}$ & $\begin{array}{c}\text { Weight gain } \\
\text { (g) }\end{array}$ & $\begin{array}{c}\text { FCR } \\
\text { (g feed } \\
\text { gg gain) }^{\text {gaing }}\end{array}$ & $\begin{array}{c}\text { Viabili } \\
\text { ty, \% }\end{array}$ \\
\hline Control & 662 & $1801^{\mathrm{b}}$ & $1139^{\mathrm{b}}$ & $4.17^{\mathrm{a}}$ & 92 \\
Citric acid (Ci) & 659 & $1901^{\mathrm{a}}$ & $1246^{\mathrm{a}}$ & $3.66^{\mathrm{b}}$ & 98 \\
Lactic acid (La) & 654 & $1892^{\mathrm{a}}$ & $1237^{\mathrm{a}}$ & $3.56^{\mathrm{b}}$ & 90 \\
Propylene glycol (Pg) & 657 & $1907^{\mathrm{a}}$ & $1254^{\mathrm{a}}$ & $3.72^{\mathrm{b}}$ & 100 \\
Cic +Pg+La & 663 & $2017^{\mathrm{a}}$ & $1357^{\mathrm{a}}$ & $3.60^{\mathrm{b}}$ & 90 \\
\hline SEM & 21 & 79 & 137 & 0.18 & 10.1 \\
\hline
\end{tabular}

a,b,c:Means within the same column with different superscripts are significantly different. $(\mathrm{P} \leq 0.5)$.

Table (7): Least square means percentages for carcass traits of growing NZW rabbits as affected by different treatments.

\begin{tabular}{|c|c|c|c|c|c|c|c|c|c|}
\hline $\begin{array}{c}\text { Treatment } \\
\text { groups }\end{array}$ & 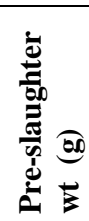 & 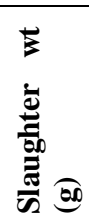 & 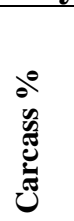 & 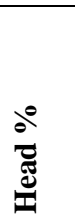 & 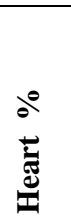 & $\begin{array}{l}50 \\
\dot{D} \\
\stackrel{D}{3}\end{array}$ & $\begin{array}{l}\therefore 0 \\
\frac{0}{2} \\
\frac{\pi}{n}\end{array}$ & 常 & $\begin{array}{l}00 \\
\frac{E}{4}\end{array}$ \\
\hline Control & 1910 & 993 & 51.99 & 10.79 & 0.42 & 5.32 & 0.06 & 1.17 & $1.41^{\mathrm{a}}$ \\
\hline Citric acid, $\mathbf{C i}$ & 1933 & 1040 & 53.80 & 10.47 & 0.40 & 5.27 & 0.07 & 1.20 & $1.28^{\mathrm{ab}}$ \\
\hline Lactic acid, La & 2043 & 1100 & 53.85 & 10.31 & 0.41 & 5.12 & 0.07 & 1.12 & $1.10^{\mathrm{c}}$ \\
\hline Propylene glycol, Pg & 1977 & 1093 & 55.29 & 9.69 & 0.41 & 5.17 & 0.08 & 1.15 & $1.07^{\mathrm{c}}$ \\
\hline $\mathrm{Ci}+\mathrm{Pg}+\mathrm{La}$ & 1990 & 1103 & 55.43 & 10 & 0.42 & 4.91 & 0.07 & 1.21 & $1.09^{\mathrm{c}}$ \\
\hline
\end{tabular}

a,b,c,.. :Means within the same column with different superscripts are significantly different. $(\mathrm{P} \leq 0.5)$.

of body weight and body weight gain. These results are in agreement with those of Noha, et al. (2013).

Improvement of the growth performance as a result of acitrol supplementation of growing rabbits, can be attributed mainly to the increase of animals resistance to pathogens and any physiological and/or environmental stress.

Finally, organic minerals will play an important role in animal and poultry nutrition, not only for meeting the true requirements of the animal for optimal performance with lower inclusion rate, but also for providing healthy meat for the consumer and harmless manure for the cropland, 
subsequently will have a pure and clean or at least not harmful crops (vegetable, fruits) and free environments (land, water) of pollution.

Conclusively, it can be concluded that supplementation of citric, lactic acids or propylene showed a great role in enhancing the immune system, improved growth performance, blood metabolites that due to improving cecum media as a results of increase total VFAs production and decrease each of total anaerobic bacterial and cecum $\mathrm{pH}$, which finally minimize pathogenic bacteria and digestive disorders.

\section{REFERENCES}

Abdel-Azeem, F., Y.M, EL-Hommosany and Nematallah, G.M. Ali., (2000). Effect of citric acids in diets with different starch and fiber levels in productive performance and some physiological traits of growing rabbits. Egyptian Journal of Rabbit Science, 10: (1): 121-145.

Agency for Toxic Substances and Disease Registry (1997). Toxicological profile for ethylene glycol and propylene glycol. Toxicological profile for Chlorpyrifos. Atlanta, GA: U.S. Department of Health and Human Services, Public Health Service.

Arrington, L. R. and P. S. Kelly, 1976. Domestic Rabbit Biology and Production. The Univ. Press of Florida, Ganesvill, USA.

Asano, T., K. Yuasa, K. Kunugita, T. Teraji and T. Mitsuoka, 1994. Effects of gluconic acid on human faecal bacteria. Microbial Ecol. Health Dis., 7: 247-256.

Ashour, G, 2001. Physiological adaptation of rabbits' kits to housing conditions as related to growth. Egyptian J. Rabbit Sci., 11:115-137.

Christopher, M.; Eckfeldt, J. and Eaton, J.(1990). Propylene glycol ingestion causes D-lactic acidosis. Laboratory investigation; 62:114-118.

Collins, C.H, P.M. Lyne, and J.M.Grange, 1995. Collins and Lyne's Microbiological Methods .Butterworth Heinemann Ltd, Oxford.

Conway, P. L. and S. Kjelleberg, 1989. Protein- mediated adhesion of lactobacillus fermentum strain 737 to mouse stomach squamous epithelium. J. Gen. Microbial., 135: 1175-1186.

Dumas, B. T., W. Watson and H. G. Biggs, 1971. Direct colourimetric method with bromo cresol green (BCG) in Plasma. Clin. Chim. Acat, $31,87$.

Duncan, D. B, 1955. Multiple range and multiple F test. Biometrics, 11:1-42.

Eadie JM, Hobson PN, Mann SO (1967). A note on some comparisons between the rumen content of barley fed steers and that of young calves also fed on a high concentrate ration. Anim. Prod., 9: 247-250 
El- Kholy, K. H. M, 2003. Amelioration of heat stress on rabbits. Ph. D. Thesis, Fac. Agric., Cairo Univ., Giza, Egypt.

El-Allawy, M. H. Hewida, 2001. The use of bio-feed additives to improve rabbit performance. Ph. D. Thesis, Fac. Agric., Cairo Univ., Giza, Egypt.

Fekete S. (1989). Recent findings and future perspectives of digestive physiology in rabbits: a review. Acta Vet Hung 1989;37:265-79.

Fuller, R. 1986. Basis and efficacy of probiotics. World's Poultry Science Journal, 44(1): pp. 69.

Hawkey, C. M. and T. B. Dennett, 1989. A Color Atlas of Comparative Veterinary Hematology. Wolf Publishing Limited., London, England.

Ismail, A. M., M. A. Abou-El-Ella and A. A. Sedki, 2002. Blood metabolites, growth and reproductive performance and immune responsiveness in growing and doe rabbits as affected by acitrol treatments. Egyptian J. Agric. Res., 80:1789-1808.

Kirchgessner, M. and F. X. Roth, 1988. Ergotrope Effekte durch organische Säuren in der Ferkelaufzucht und Schweinemast. Übersichten zur Tierernährung, 16:93- 108.

Luzi F.,E.L, Heinzl ,M. Zecchini ,S.Barbieri ,S.Leoni and C.Crimella (2000). Effect of propylene glycol in rabbit reproductive performance. World Rabbit Science Association, Volume 8, supplement 1, Volume A, : 179-184

McWilliams, D. A. (2001). Nutritional pathology in rabbits: current and Future perspectives. Ontario Commercial Rabbit Growers Association Congress, $1: 21$.

Merck, E., 1974. Clinical Laboratory, 11th Ed. Of Micro-chemical Investigation Methods. Darmstadt, Federal Republic Germany.

Miller, B.F, 1987. Acidified poultry diets and their implications for the poultry industry. In T.P. Lyons (ed). Biotehnology in the Feed Industry. Alltech Technical Publications, Nicholasville, Kentucky, pp 199-208.

Miller, O. N. and Bazzano, G. (1965). Propanediol metabolism and its relation to lactic acid metabolism. Ann NY Acad Sci 119, 957-73.

Noha, M.A.Mohamed; Sedki, A.A.; Faten, A.A.Ibrahim and ELKaiaty.M.(2013). Effect of sodium gluconate, mannan oligosaccharide and potassium diformate on performance of growing New Zealand White rabbits. Egypt. Poult. Sci., Vol (33) (I): 73-85

Noha,M.A.Mohamed; Faten, A.A.Ibrahim;A.A.EL-Far and A. A Sedki (2006). Effect of supplemental acidfiers on physiological and productive performance in weaning rabbits. Journal of Agriculture Science Mansoura Univ., 31(2):683-690. 
Parks, C. W.; J. L. Grimes; P. R. Ferket and A. S. Fairchild 2000. The case for mannanoligosaccharides in poultry diets. An alternative to growth promotion antibiotics? In: Biotechnology in the Feed Industry. Proceeding of the 16th Annual Symposium (T. P. Lyons and K. A. Jacques, eds). Nottingham Univ. Press. Nottingham, Leics. UK. pp. 45-59

Poeikhampha, T. and C. Bunchasak, 2010. Effect of sodium gluconate on $\mathrm{pH}$ value, ammonia and short chain fatty acids concentration in batch culture of porcine cecal digesta. J. Applied Sci., 10: 1471-1475.

Poeikhampha, T., C. Bunchasak, S. Koonawootrittriron, K. Poosuwan and K.Prahkarnkaeo. 2007. Effects of sodium gluconate on production performance and intestinal microorganisms of starter piglets, pp 74-77. In: Proc. Int. Conf. on "Integration of Science \& Technology for Sustainable Development" (Ed. K. Soytong and K. D. Hyde), Faculty of Agriculture Technology, King Mongkut's Institute of Technology Ladkrabang, Bangkok

Pollman, D.S, 1986. Recent Advances in Nutrition. W. Haresign and D.J.A. Cole (eds), Butterworths, Boston, USA, pp. 113-146.

SAS. (2004). SAS User's Guide: Statistics. Version, Fifth Edition. SAS Institute Inc., Cary NC., USA.

Sedki, A. A., A. M. Kaiaty and G. Ashour, 2002. Physiological performance indices of rabbits' adaptability under untraditional housing condition. 3rd Sci. Con. Rabbit Prod. in Hot Climates, 8-11 October 2002, Hurghada, Egypt, pp.351-365.

Seidenfeld M. A. and P.I. Hanzlik (1932). General properties. Action and toxicity of propylene glycol. J. Pharmacol. Exp. Ther., 44, 109-121.

Smits, R. J. and D. J. Henman (2000). Practical experiences with Bioplexes in intensive pig production. In: biotechnology in the feed industry. Proceeding of the 16th Annual Symposium (T. P. Lyons and K. A. Jacques, eds). Nottingham Univ. Press. Nottingham, Leics. UK. pp. 293-300.

Snedecor, G.W. and Cochran, W.G. (1982). Statistical Methods. 7th Edition, Iowa State University Press, Towa, 511.

Tsukahara, T.; Koyama, H.; Okada, M.; Ushida, K. 2002. Stimulation of butyrate production by gluconic acid in batch culture of pig cecal digesta and identification of butyrate-producing bacteria. Journal of Nutrition, Vol. 132, No. 8: 2229-2234.

Wittman, J. and Bawin, R. (1974). Stimulation of gluconeogenesis by propylene glycol in the fasting rat. Life Sciences, 15: 515-524. 
IMPACT OF ADDINGCITRIC,LACTIC ACIDS \& PROPYLENE GLYCOL INRABBITS 323

\section{تأثير إضافة حامض اللاكتيك والستريك والبروبلين جليكول

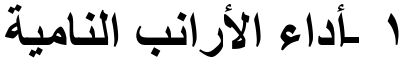

حسن محمود الكيلاوي،*عبد المنعم عبد الرحمن صدقي***محمد نصر الله***، نهي

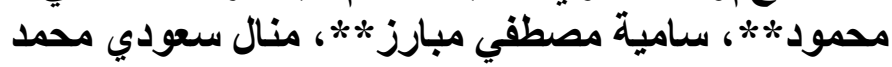

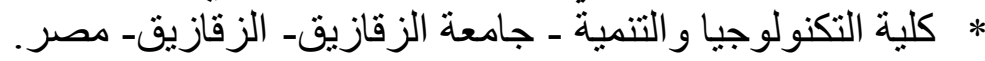

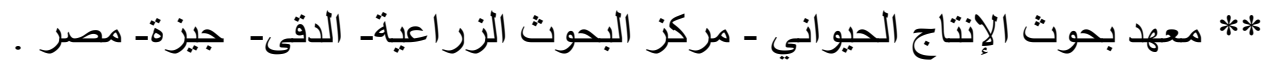

أجريت التجربة علي الأرانب النيوزيلندي المفطومة لتحديد تأثير الأحماض

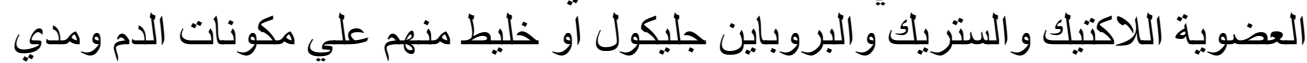

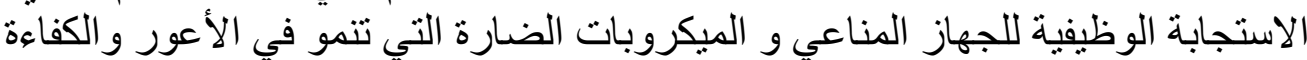

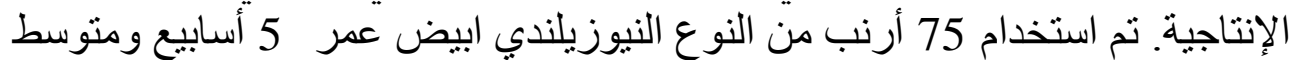

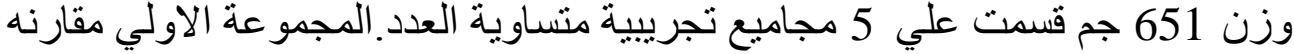

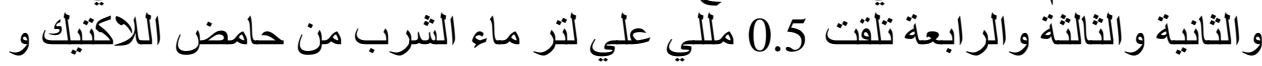

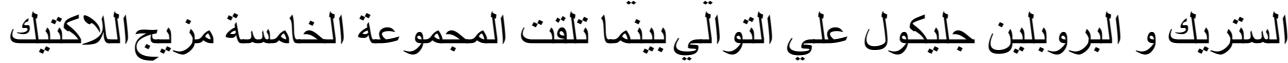
و الستريك و البروبلين جليكول بمعدل0.25 ملائي لكل منهم.

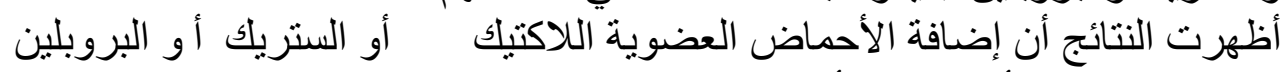

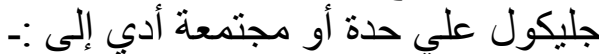
1. انخفاض عدد الميكروبات الضارة بالاعور الفي للأر انب التي تمت الإضافة إلى مياه الشرب لها. ץ. تحسنت قيم الهيماتوكريت، الهيموجلوبين وازدادت خلايا كر ات الدم البيضاء الكلية و الليمفوثايتس و انخفضت نسبة النيتروفيل عن الليمفوثاليتس.

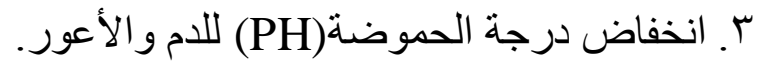

ع. انخفاض معنوي فى اعدادالبكنيريا اللاهو ائية ودرجة دورة حموضة الأعور وكذلك تركيز

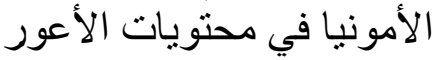

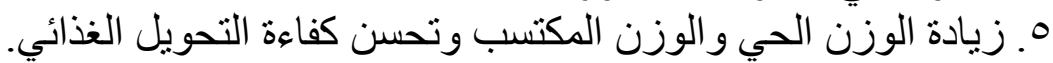

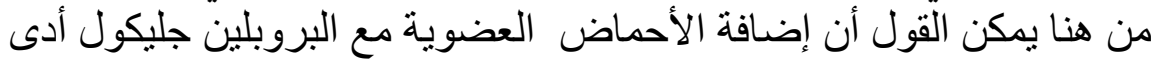

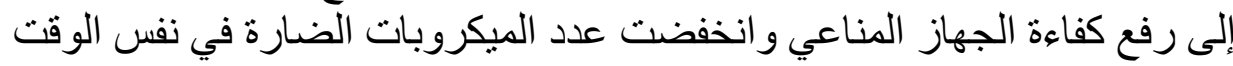

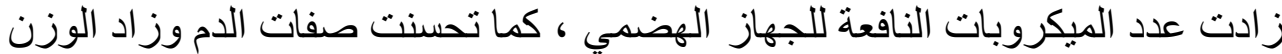

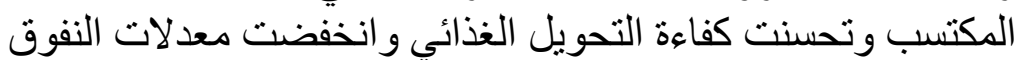

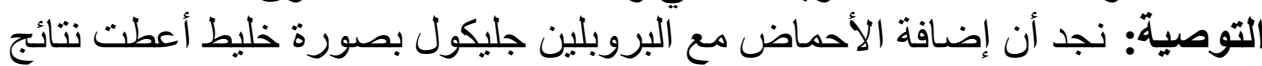
اعلي من الصور الفردية مما يدل علي وجود صنفة الإنة تعاون بينهما. 